\title{
Sciendo
}

DOI: $10.2478 /$ rjp-2019-0005

Rom J Psychoanal 2019, 12(1):67-80

Rom J Psychoanal

\section{THE ARCHAIC, THE INDUCEMENT OF A RE-HISTORICIZATION...}

Bogdan Sebastian Cuc ${ }^{6}$

Abstract: Exploring the archaic, as a space-time unit that we can only identify as such in après-coup, leads us to strange, peculiar experiences whose manner of emergence in the here and now of the cure lead to re-configurations of the interactions inside the consulting room. Placed in a personal pre-history, connected with the fusion and de-fusion experiences, the archaic may represent for the psychoanalytic situation the occasion of re-writing the history, a history that starts from the same pre-history, but which is reconfigured in other possible histories ... The histories we hear, but also those we build inside the analytical process, are carried out under the pressure of the archaic experiences penetrating the analytical situation in the negative of the present forms.

Keywords: archaic, transformation, displacement, inscription, psychic integration, reverie.

${ }^{6}$ Romanian Society of Psychoanalysis; bogdan.cuc@gmail.com 
The matter of the archaic has become a concern for me as a result of the clinical experiences in which the space-time landmarks of the analytical situation were peculiarly penetrated by forms of expression that seemed to usher in elements in dissonance with the patient's usual discourse. There are times when the transference-countertransference flow stops, suspended in a form of communication that requires access to another language, a non-elaborate language to which the logos finds no path. Attempting to manage these situations, I've started from two important landmarks belonging to the Freudian heritage.

The first landmark is that in which Freud, as a consequence of the formulation of the second topography, proposes the Id, an instance placed between the Ego and the somatic, that is, between the psychic area that can become conscious and the area we can assume lies beyond what can bear the attribute of unconscious. The idea that there are experiences belonging to human reality that are beyond integration inside the psychic area, conscious or unconscious, is the one which allows the phantasy and construction of a possible mechanism of integration into the analytical situation of the strange elements that cannot be included in classical transference interpretations. As Freud points out, the elements present inside the Id are subject to the laws of the economic principle, so they have no intentionality; they only aim at achieving satisfaction, in accordance with the pleasure principle.

What seems interesting to me and therewith useful for this presentation is the way in which Freud highlights the negative exploration of Id elements as the only way to access contents that have no meaning in the rhetoric of the usual logos of the patient's speech on 
the couch. On the other hand, the space-time suspension of the elements of the Id, which Freud speaks of, in the absence of reference marks "so dear to philosophers", provides a good enough reference to integrate uncanny sequences that reside during the presence of the patient in the consulting room; the patient who, being in regression, is suspended in a form of presence beyond the reach of logos.

The second landmark, though written by Freud earlier, was brought to the attention of psychoanalysts later, in a less direct, almost "unofficial" way, when Freud, in a letter to his friend Fliess (the famous letter 112 of December $\left.6^{\text {th }} 1896\right)$, tells him about mnemic traces and the way experiences are placed in layers: perceptions (Wahrnehmungen), traces of perceptions (Wahrnehmungszeichen), unconsciousness (Unbewusstsein), pre-consciousness (Vorbewusstsein) and consciousness (Bewusstsein). If at the perceptual level "consciousness and memory are mutually exclusive" (Freud, 2006, p. 264), at the second level of the indication of perceptions (Wahrnehmungszeichen), the first registration of perceptions occurs, organized in associations by simultaneity. The next layer, that of the unconsciousness, the one of the second registration (second re-transcription), but which starts from the material of the first registration of the indication of perception (Wahrnehmungszeichen), organizes them according to other criteria, probably causal criteria. From this level, psychic inscriptions seek access to consciousness. For Freud these successive inscriptions and re-inscriptions are forms of translation, in layers, from one level to another, from one language to another, to the level of secondary elaborations that begin at the level of preconsciousness (Vorbewusstsein) related to word-representations. 
I find it extremely interesting how this discovery, which belonged to Freud's private space, comes to validate and complement the official discourse of the father of psychoanalysis, all the more so as it is a very early testimony related to the birth and evolution of psychoanalysis. Besides, these early elaborations of Freud are extremely interesting from the perspective of current neuroscience research, but I will not develop this topic here.

In both texts we have found emphasis on the presence of different manifestations found in the human being, that cannot be integrated, that are not yet integrated, or that are only partially integrated in the psychic. Bion takes on this perspective later, when he brings forth the reality of " $\mathrm{O}$ " and beta elements. But the most important thing is that, in both texts, Freud proposes a way of approaching the elements that cannot be taken into the logos, a way that involves the analyst's work in après-coup, a form of integration with and by his own experiences that belong to that period of prehistory, that is to say, that period before the logos, before the period of the word integration, before the period of the meaningful discourse, or, as Freud says in his letter to his friend, before all the acquisitions “corresponding to our official ego" (Freud, 1887-1904, p. 265).

So the exploration of the archaic, as a space-time unit that we can only identify as such in après-coup, leads us to strange, peculiar experiences whose manner of emergence in the here and now of the cure lead to re-configurations of the interactions inside the consulting room. Placed in a personal pre-history, connected with the fusion and de-fusion experiences, for the psychoanalytic situation the archaic may represent the occasion of re-writing history, a history that starts from the same pre- 
history, but which is re-configured in other possible histories... The histories we hear, but also those we build inside the analytical process, are carried out under the pressure of the archaic experiences penetrating the analytical situation in the negative of the present forms. What I consider to be the key to accessing these realities is Freud's stratified perspective on the psyche, allowing us to understand how successive inscriptions and re-inscriptions admit the displacement or the transformation, according to Bion's theory of the free energy from one representation to another, towards the psychic integration of personal experiences.

Another issue that I consider important when exploring the archaic is that of the form of representation of archaic realities. There are many ways to consider the archaic: as phantasy unfolding based on possible experiences that are lost in the darkness of time, as pre-psychic organizational mechanisms, only accessed at certain regression moments, or as contents that have been preserved in forms of organization under the principle of pleasure. Personally, I turn to the last option. The arguments that make me relate to archaic realities as contents and not mechanisms or fantasies also come from Freud's description of the Id.

"It is filed with energy reaching it from the instincts, but has no organisation, produces no collective will, but only a striving to bring about the satisfaction of the instinctual needs subject to the observance of the pleasure principle. (...) Wishful impulses which have never passed beyond the id, but impressions, too, which have been sunk into the id by repression, are virtually immortal; after the passage of decades they behave as though they had just occurred. They can only be recognized as 
belonging to the past, can only lose their importance and be deprived of their cathexis of energy, when they have been made conscious by the work of analysis, and it is on this that the therapeutic effect of analytic treatment rests to no small extent" (Freud, 1933, p. 57-79).

The only reference Freud speaks of is a dynamic one - in order to become a mechanism, it is necessary to develop a structure with repetitive elements that ensure the legitimacy. However, these elements are missing from the contents present in the Id and from the contents that penetrate the present with forms belonging to prehistory. On the other hand, the organisation of archaic elements in phantasy, that is putting them in the progress of the temporal landmarks, is also impossible due to the absence of these landmarks inside the non-time and the non-space of the Id. I believe that these contents are non-processual, so they cannot fit into the rhetoric of the phantasy, which, through its deployment,

performs sequences that alternate rhythmically, having a temporal organization.

But with all these considerations, the archaic elements can become raw material for the phantasy or for the dream processes in handling concrete situations inside the consulting room, when the patient discourse is suspended in a way that makes the analytical workingthrough impossible, the one Freud wrote about as the only one able to bring historical elements into the historical order.

\section{Marius from Stories to Space}

Marius constantly used to show up for the sessions on time and never missed any. He used to come in and, after the usual greeting which 
never lacked a smile, he would lie down on the couch with his feet hanging down. It seemed as if he didn't have enough space. At first, strangely enough, I didn't take this into account, especially because I had other patients who, due to their height, chose not to lie down on the couch, with their legs folded. At the beginning of the session, almost every time, after a pause during which he seemed to gather his thoughts, he began to talk and relate daily happenings that seemed like puzzles we had to solve together. He hardly ever brought up dreams. His speech was rendered in a language that, without being precious, was seductive by the references he frequently made. He seemed to associate with ease and a freedom that was gratifying for me. Captivated by the line and the intellectual level of his speech, I often found myself asking what we were doing there. I was thinking of a collusion, of an intellectual seduction, or of a homosexual seduction - elements of a paternal transference that seemed the most plausible premise in the context of his history. Marius never knew his father. He was raised by his mother and his maternal grandmother, and the only important male character in his life was the basketball coach. His formula was: "The only man who mattered in my life was, "unc* Gică"7 , the basketball coach".

When I heard the way he formulated, I thought how strange it was to hear this from a man, as if I could not hear the suffering of the father's absence, the anguish, the inability to mourn for a man he knew nothing about, or about whom the only thing he knew was what his mother had told him: "It's not worth telling you about him".

${ }^{7} \mathrm{~N} / \mathrm{A}$. Not really an uncle, term used to show respect. 


\section{The sessions announcing the rewriting of the stories}

While I was listening to his stories, the histories that seemed brought forth in order to be deciphered, besides the question of what we were doing there, that accounted more to my defence of the presence of a man whose intellectual reach I seemed to be enjoying maybe too much, according to the rules of my profession. From time to time, I felt embarrassed that he could not fit with his feet on the couch. It was a thought, or rather a sensation, which I did not relate to for a while, and I even thought I should order a larger couch to accommodate any patient... all patients. It seems I wasn't spacious enough, a phantasy that couldn't have come from the male identification register.

About two months after these phantasies started to be present in my mind, he came to a session with the same greeting, accompanied by a smile. He lay down on the couch, only this time he had both feet on it, his knees slightly bent, but in a relaxed position. The first thought that came to mind was remembering his image with his feet hanging off the couch: how tense he was when lying down on the sofa with his feet hanging! How had I not noticed it until now?!?!?

After he lay down he started in the same way, telling me about everyday happenings that he and I had to decipher together. After a few minutes, he stops the story and silently starts to take rapid shallow breaths that seemed to accelerate. After a silence in which one could only hear his breathing, jerky, heavy, accelerated, he began to speak with a voice that did not seem to belong to him. Normally, the rhythm of his usual speech was alert, voice inflections tuned to the discourse's content, 
but this time it was muffled, without inflections. "How strange ... I just noticed I have enough space on the couch for my legs... precisely now, one day after I found out that my mother is sick."

The news of his mother's incurable illness had so far been absent from the ritual in which Marius' sessions regularly took place. After speaking, he sat in a foetal position and began to cry, almost without a sound. At that time, I associated the change of position with a regressive trend to seek comfort, to seek something from the story of the relationship with his mother. I did not interpret anything; I just let his moment of crying unfold.

The sessions continued in roughly the same pattern as from the beginning of the therapy, except that everyday stories were about his mother's disease, about the things he was supposed to take care of. That lasted a few months until his mother died. During all this time, he never stood with his feet on the couch, he was back to his usual position, the one he'd been sitting in until then, but in the same tension, which I could now see, which I could now receive...

About three to four months after his mother's death, he came to the first session of the week (from a four-session frequency) and he lay down with his feet on the couch, relaxed, his hands folded under his head, like he'd never stood before, and said, "I had fun this weekend. I went to the seaside with some friends, in a jiffy."... Then he stopped and I almost heard a smile. 
It seemed to me like he had just awoken from a dream. So did I. Then I remembered the change of position from the session when he told me about his mother's illness. At the same time, I realized that, from that moment on, I had never thought of the couch and the idea of looking for a larger one.

I said, "It's interesting that you've changed your position and now you have enough space on the couch". I said that without having formulated it in my mind, it just came out.

He immediately answered as if from a dream: "I wonder why I did not find the couch spacious enough when my mother was still alive". Then he went silent and after a few minutes he began to tell me how he had fun during the weekend.

I didn't answer. I kept silent and I asked myself, again, how I had not noticed the tension he exhibited when sitting on the couch before the meeting in which he told me about his mother's illness. And I thought that, although, after that moment, I began noticing his tension, I tolerated it, without signalling it to him in any way, but especially without thinking about how, before that moment, I had not noticed it.

After this session, his speech changed. Everyday stories began to diminish as a presence, and the puzzle aspect to be deciphered disappeared altogether. However, the most important thing was how he brought up memories and dreams, in a way that showed he was no longer preoccupied by the form of his speech, but by the search for a space for himself. The space he was looking for was the one where he had to leave 
his mother's womb and to which, I believe, he felt he was not yet ready to go.

We discussed these two sessions, placed at the two ends of a mourning process for a mother who he seemed to have found again in another shape, but, most importantly, in another space, several times after that in Marius's analysis. But what I kept in mind, as an extremely important and triggering element in the process that followed, was the dialogue between the rhythm of his speech and the tension of his body. It was a breakthrough that made me think about the baby's observation, the experiences of working with abandoned children in the orphanage, the tension in the body of abandoned and un-stimulated babies who refused to be touched. In other words, I was referring to the forms of body organization that seem to be supported by a pulsating force, for which the only thing that counts, is to be satisfied, as Freud wrote.

The experience with Marius was an experience of transforming the tension that was concentrated in his body, a tension that brought forth his resistance to the archaic anxiety of devouring. To not interfere, to not interpret, to accept, to tolerate, to contain this tension was the experience of integration of the archaic elements that could come from tensions accompanying the birth of a child, probably undesired, probably received with ambivalence, in a very fraught historical time, especially in relation to pregnancy and births. However, all of this comes from my fantasies, from my associations with what I know of those times, about the Decree 770 generations that Marius was part of, from the way I made my dream about Marius... 
Doing, together and separately, the dream of the changes that accompanied Marius' development was a work experience of mental figurability, as César and Sara Bottela describe in " $L a$ figurabilitépsychique", "...working through the figurability produces the intelligibility of the dream" (César et Sara Bottela, 2007, p. 83). For Marius, this change was found unto a series of changes that he made in his life, all directly related to the space, with a transitionality process that he had, until that point, experienced only through words, or at contact interactions, body friction, through sports-specific disputes. The difference between the two-forms of dreaming, but, especially, the acceptance of incompatible differences between my dream and that of Marius, represented, I think, another important aspect in the process, a key issue even. The fact that I did not share my fantasies about the possible difficulties of having being birthed by a mother perhaps ambivalent or maybe a mother who did not want him, allowed the preservation of a space where Marius was able to build his own dream, was able to build a space for him. I think that's what Laurence Kahn refers to when she talks about the abstinence of sharing, as a precondition for the perception of the vibration exerted by the patient, vibrations which, once perceived, give us access to archaic explorations, to the devouring anxiety, to different forms of body expressions.

"In this area, everything the analyst communicates about his expectations, his personal inclinations, or his emotions, contributes without delay to a further distortion of the transference." (Laurence Kahn, 2014, p. 136) 


\section{Conclusion}

As a conclusion to Marius's analysis, I would say, first of all, that the repetition in the first part of the analysis of a discourse which, although bringing in a lot of contents and forms of Oedipal transference, by looking for a father in relation to whom he wanted to build himself in the negative of his absence, had a circular, stagnant dynamic, out of which he only managed to get when he found out about the news of his mother's illness. The way he signalled the two dynamics, the two situations, was through the tension of a position in which he was partially inside (on the couch) and partly outside (beside the couch), without the situation being clear to me, not even now - was he entering or was he exiting. The major change in his discourse and the unlocking of the process was possible after the release of that tension, which in après-coup is similar to the muscular contraction of a baby who refuses to be touched.

For me, this dynamic unfolded through a discharge in two dream speeches that were able to generate the phantasy which created the temporality of those archaic elements that then allowed the emergence of space and transitionallity, leading to the integration of those archaic elements blocking the process, in turn blocking Marius's evolution.

\section{REFERENCES}

ANZIEU, D. (1985). Le Moi-peau [The Skin-Ego]. Dunod, Paris, 1995, pp. 57-88, pp. 93-178. 
BOtTElA, C., BOTTELA, S., La figurabilité psychique [The psychic figurability]. In Press Èditions, 2007, p. 83.

FREUD, S. (1887-1904). Lettres à Fließ1887-1904 [Letters to Fliess 1887-1904]. PUF 2006, pp. 262-273.

FREUD, S. (1915). The unconscious. SE XIV. Hogarth Press, London, pp. 159-215.

FREUD, S. (1933). New Introductory Lectures on Psycho-analysis XXXI.

The Dissection of the Psychical Personality. SE XXII. Hogarth Press, pp. 57-79.

GREEN A (1986). Le travail du négatif [Working through the negative]. Les Èditions de Minuit 2011, pp. 373-387.

GREEN A (1999). On Discriminating and not Discriminating Between Affect and Representation. Int J Psychoanal 80 (2):277-316.

KHAN, L. (2014). Le psychanalyste apathique et le patient postmoderne [The apathetic psychoanalyst and the postmodern patient]. Èditions de l'Olivier, 2014, p. 136.

MARINOV, V. (2008). Introduction: l'archaïque, unehistoireen-deçà des mots", [Introduction: the archaic a story below the words] in L'archaïque [The Archaic]. EDK 2008, p. 11. 